\title{
PERBEDAAN NHT BERBANTU KARTU DAN DISKUSI UNTUK MENINGKATKAN AKTIVITAS DAN HASIL BELAJAR AKUNTANSI
}

\section{DIFFERENCE NHT ASSISTED CARD AND DISCUSSION TO INCREASE ACTIVITY AND ACHIEVEMENT IN ACCOUNTING LEARNING}

\author{
Oleh: \\ Ristiningsih Mulyawati \\ Prodi Pendidikan Akuntansi Universitas Negeri Yogyakarta \\ mristiningsih@ymail.com \\ Sumarsih \\ Staf Pengajar Jurusan P. Akuntansi Universitas Negeri Yogyakarta
}

\begin{abstract}
Abstrak
Penelitian ini bertujuan untuk mengetahui perbedaan penerapan Model Pembelajaran Kooperatif Tipe Numbered Heads Together (NHT) Berbantu Media Kartu dan Diskusi dalam meningkatkan Aktivitas dan Hasil Belajar Akuntansi siswa kelas X Akuntansi SMK Negeri 1 Pengasih. Penelitian ini merupakan penelitian Quasi Eksperimental. Terdapat kelas eksperimen yang diberi perlakuan Tipe NHT Berbantu Kartu, kelas kontrol dengan Diskusi. Pengumpulan data menggunakan lembar observasi, angket, dan tes kemudian dianalisis dengan uji-t. Hasil penelitian pembelajaran NHT berbantu kartu lebih meningkatkan Aktivitas dan Hasil Belajar Akuntansi dibandingkan dengan Diskusi. Perbedaan signifikan ditunjukkan dari hasil uji-t Aktivitas Belajar Akuntansi $t_{\text {hitung }}>t_{\text {tabel }}$ $(3,178>2,00030)$. Uji-t Hasil Belajar Akuntansi diperoleh $t_{\text {hitung }}>t_{\text {tabel }}(4,247>2,00030)$. Perbedaan Aktivitas Belajar Akuntansi juga dapat dilihat dari peningkatan persentase observasi sebesar $13 \%$ di kelas eksperimen, kelas kontrol 9\%, peningkatan persentase angket kelas eksperimen 4\%, kelas kontrol 3\%. Rata-rata selisih posttest-pretest materi I kelas eksperimen lebih tinggi sebesar 13,75\%, kelas kontrol 7,03\%, sama halnya dalam materi II kelas eksperimen lebih tinggi sebesar 45,13\%, kelas kontrol 24,61\%. Ketuntasan belajar kelas eksperimen materi I terdapat 96,77\% siswa tuntas, kelas kontrol 93,75\%. Materi II di kelas eksperimen terdapat 93,75\% siswa tuntas, kelas kontrol 75\%.
\end{abstract}

Kata kunci: Aktivitas Belajar Akuntansi, Hasil Belajar Akuntansi, Model Pembelajaran Kooperatif Tipe NHT, Kartu, Metode Diskusi.

\begin{abstract}
The objectives of this research were to determine difference between implementation of Cooperative Learning Model Numbered Heads Together (NHT) Assisted Card Media and Discussion Method in increasing Activity and Achievement in Accounting Learning students grade $X^{\text {th }}$ Accounting Major of SMK Negeri 1 Pengasih. This research was a Quasi Experimental. There was experiment class treated Learning Model NHT assisted Card and control class treated Discussion. Collecting data used observation sheets, questionnaires, and tests which analyzed by t-test. The results showed that learning Model NHT assisted Card had a higher increased of Activity and Achievement students in Accounting Learning compared with Discussion. Difference significant showed by the results of t-test for Accounting Learning Activity $t_{\text {count }}>t_{\text {table }}(3,178>$ 2,00030). T-test for Accounting Learning Achievement $t_{\text {count }}>t_{\text {table }}(4,247>2,00030)$. Differences in Accounting Learning Activity can also be seen from the increased of observation percentage $13 \%$ in experiment class, control class 9\%, percentage increase of questionnaires in experiment class result 4\%, control class 3\%. Difference average posttest-pretest in first material, experiment class had a higher result of $13.75 \%$, control class $7.03 \%$, the same as in second material, experiment class was higher by $45.13 \%$, control class 24.61\%. In first material, mastery learning of experiment class found students who completed
\end{abstract}


$96.77 \%$, control class $93.75 \%$. In second material, mastery learning of experiment class found $93.75 \%$ of students who completed, control class $75 \%$.

Keywords: Accounting Learning Activity, Accounting Learning Achievement, Cooperative Learning Model Numbered Heads Together (NHT), Card, Discussion Method.

\section{PENDAHULUAN}

Pendidikan merupakan suatu proses belajar yang dilakukan sepanjang hayat. Pada era globalisasi dituntut kualitas Sumber Daya Manusia (SDM) yang berkualitas tinggi dan dapat bersaing. Berdasarkan tuntutan tersebut maka diperlukan suatu usaha untuk memajukan pembangunan negara dalam bidang pendidikan. Pendidikan dapat diwujudkan dalam proses belajar mengajar yang menimbulkan interaksi antara dua unsur yaitu pendidik dan peserta didik. Kualitas pendidikan di sekolah pada umumnya dapat dilihat dari hasil belajar siswa. "Hasil belajar adalah kemampuankemampuan yang dimiliki siswa setelah Ia menerima pengalaman belajarnya" (Nana Sudjana, 2011: 22). Usaha untuk meningkatkan hasil belajar siswa bukanlah suatu usaha yang mudah. "Belajar pada hakikatnya adalah perubahan yang terjadi dalam diri seseorang setelah berakhirnya melakukan aktivitas belajar" (Syaiful Bahri Djamarah, 2013: 38). Berdasarkan hal tersebut, maka aktivitas belajar sangat diperlukan untuk menunjang kelancaran kegiatan belajar siswa sehingga materi yang disampaikan dapat diterima dengan baik oleh siswa.

Berdasarkan observasi awal yang dilakukan pada tanggal 5 dan 18 November 2014 di kelas X Akuntansi 1 dan X Akuntansi 2 SMK Negeri 1 Pengasih yang terdiri atas 32 siswa di setiap kelas, ditemukan beberapa masalah yaitu siswa kurang aktif selama proses pembelajaran berlangsung. Metode ceramah yang diselingi dengan diskusi kelompok kecil siswa dengan teman sebangkunya belum mampu meningkatkan Aktivitas dan Hasil Belajar Akuntansi siswa. Hal tersebut ditunjukkan dengan rendahnya aktivitas siswa yang berhubungan dengan kegiatan pembelajaran, siswa yang melakukan aktivitas yang berhubungan dengan kegiatan pembelajaran hanya sebanyak $40 \%$ yang berarti $60 \%$ siswa memiliki aktivitas belajar yang masih rendah. Selain itu, proses pembelajaran yang berlangsung di kelas masih jarang menggunakan model dan media yang bervariasi. Metode mengajar yang biasanya digunakan oleh guru adalah metode diskusi untuk mengerjakan soal latihan, namun dalam penerapannya masih kurang efektif. Kebiasaan tersebut mempengaruhi Hasil Belajar Akuntansi siswa. Dilihat dari nilai Ulangan Tengah Semester (UTS) masih banyak siswa yang belum memenuhi Kriteria Ketuntasan Minimal (KKM) yang telah ditetapkan yaitu 77. Siswa yang belum mencapai KKM di kelas X Akuntansi 1 sejumlah 12 siswa dari 32 siswa atau sebesar $37,5 \%$, sedangkan di kelas X Akuntansi 2 terdapat 20 siswa yang tidak mencapai KKM dari 32 siswa atau sebesar $62,5 \%$.

Model pembelajaran kooperatif dapat dimanfaatkan oleh guru sebagai alternatif pembelajaran yang inovatif dan sekaligus dapat meningkatkan Aktivitas dan Hasil Belajar Akuntansi siswa. Salah satu model pembelajaran kooperatif yaitu Numbered Heads Together (NHT). Langkah dalam NHT yaitu, penomoran, mengajukan pertanyaan, berpikir bersama, dan menjawab pertanyaan. Menurut Trianto (2012: 82) NHT digunakan untuk melibatkan lebih banyak siswa dalam menelaah materi yang tercakup dalam suatu pelajaran dan mengecek pemahaman mereka terhadap isi pelajaran tersebut. Model pembelajaran tipe NHT perlu didukung oleh media pembelajaran agar dalam penerapanya dapat membangkitkan ketertarikan siswa sehingga Aktivitas dan Hasil Belajar Akuntansi akan meningkat. Salah satu media yang cocok digunakan dalam teknik ini yaitu media kartu. "Kartu adalah kertas tebal yang berbentuk persegi panjang 
(http://kbbi.web.id/kartu)". Kartu yang digunakan dalam penelitian ini adalah kartu pintar dan kartu soal. Kartu pintar adalah kartu yang berisi ringkasan atau pokokpokok materi pembelajaran, sedangkan kartu soal merupakan kartu yang berisi soal-soal yang harus dijawab oleh siswa.

Guna membuktikan peningkatan Aktivitas dan Hasil Belajar Akuntansi siswa, maka peneliti membandingkannya dengan kelas lain yang tidak diberi perlakuan Model Pembelajaran Kooperatif tipe Numbered Heads Together (NHT) Berbantu Media Kartu dalam kegiatan pembelajaran akuntansi. Metode yang biasa digunakan guru dalam proses pembelajaran adalah Metode Diskusi. Metode Diskusi adalah metode pembelajaran yang menghadapkan siswa pada suatu permasalahan (Wina Sanjaya, 2013: 154). Oleh karena itu peneliti mencoba untuk melakukan penelitian yang berjudul "Perbedaan Model Pembelajaran Kooperatif Tipe Numbered Heads Together (NHT) Berbantu Media Kartu dan Metode Diskusi dalam Meningkatkan Aktivitas dan Hasil Belajar Akuntansi Siswa Kelas X Akuntansi SMK Negeri 1 Pengasih Tahun Ajaran 2014/2015". Penelitian ini dibatasi pada: (1) Materi pembelajaran yang akan diukur Aktivitas dan Hasil Belajar Akuntansi adalah akuntansi perusahaan jasa dalam materi pokok pencatatan pada buku jurnal umum dan pemrosesan entri jurnal. (2) Pengukuran aktivitas belajar dibatasi pada aktivitas yang berkaitan dengan pembelajaran akuntansi. (3) Pengukuran Hasil Belajar Akuntansi dibatasi pada ranah kognitif. (4) Ranah kognitif yang diukur adalah pengetahuan $(\mathrm{C} 1)$, pemahaman $(\mathrm{C} 2)$, dan aplikasi (C3).

\section{METODE PENELITIAN}

\section{Jenis Penelitian}

Penelitian ini merupakan penelitian eksperimen. Penelitian eksperimen adalah penelitian yang memberikan perlakuan (manipulasi) terhadap variabel penelitian (variabel bebas), kemudian mengamati konsekuensi perlakuan tersebut terhadap objek penelitian (variabel terikat). Metode penelitian yang digunakan dalam penelitian ini adalah metode eksperimen semu (quasi experimental). "Quasi experimental digunakan karena pada kenyataanya sulit mendapatkan kelompok kontrol yang digunakan untuk penelitian" (Sugiyono, 2012: 114).

\section{Waktu dan Tempat Penelitian}

Penelitian ini dilaksanakan di SMK Negeri 1 Pengasih yang terletak di Jalan KRT. Kertodiningrat 41, Kecamatan Pengasih, Kabupaten Kulonprogo, Yogyakarta. Penelitian ini dilaksanakan selama empat bulan yaitu dari Bulan November 2014 hingga Maret 2015. Waktu penelitian terhitung sejak pemilihan judul dan pelaksanaan penelitian sampai pada penyusunan laporan penelitian sebagai hasil dari penelitian.

\section{Target/Subjek Penelitian}

Subjek dalam penelitian ini adalah siswa kelas X Akuntansi 1 dan X Akuntansi 2 SMK Negeri 1 Pengasih tahun ajaran 2014/2015 yang terdiri atas 32 siswa di masing-masing kelasnya, siswa kelas $\mathrm{X}$ Akuntansi 2 sebagai kelas eksperimen sedangkan yang menjadi kelas kontrol adalah siswa kelas X Akuntansi 1.

\section{Prosedur}

Rancangan penelitian yang digunakan untuk perbedaan Hasil Belajar Akuntansi menggunakan bentuk one group pretest posttest design.

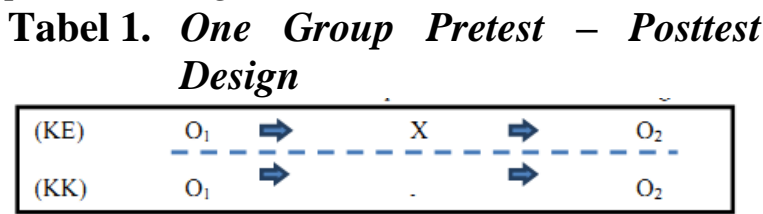

Sedangkan untuk mengetahui perbedaan Aktivitas Belajar Akuntansi menggunakan bentuk Posttest only control design. 
Tabel 2. One Group Pretest - Posttest Design

$(\mathrm{KE})$
$(\mathrm{KK})$

Keterangan:

(KE) : Kelas Eksperimen

(KK) : Kelas Kontrol

X : Model Pembelajaran Kooperatif

Tipe NHT Berbantu Media Kartu

- $\quad$ : Metode Diskusi

$\mathrm{O}_{1} \quad$ : Pre test

$\mathrm{O}_{2} \quad$ : Post test

Berdasarkan rancangan penelitian, maka langkah-langkah penelitian yang dilaksanakan dengan berpedoman pada pendapat Amat Jaedun (2011: 8) adalah sebagai berikut: (1) Mempersiapkan instrumen yang berupa instrumen pembelajaran dan instrumen penelitian. (2) Menentukan kemampuan awal Hasil Belajar Akuntansi siswa dalam kemampuan kognitif siswa atas kedua materi pokok sebelum diberi perlakuan dengan cara memberikan soal pre test pada kelas eksperimen dan kelas kontrol. (3) Menerapkan perlakuan pada kelompok eksperimen berupa penggunaan Model Pembelajaran Kooperatif Tipe NHT Berbantu Media Kartu dan menerapkan perlakuan pada kelompok kontrol berupa penggunaan Metode Diskusi. (4) Menentukan kemampuan akhir Hasil Belajar Akuntansi siswa atas kedua materi pokok setelah diberi perlakuan dengan cara memberikan soal post test pada kelas eksperimen dan kelas kontrol. Selain kemampuan kognitif, Aktivitas Belajar Akuntansi siswa juga diukur dengan menggunakan angket. (5) Menentukan selisih nilai post test dan pre test Hasil Belajar Akuntansi aspek kognitif kelas eksperimen. (6) Menentukan selisih nilai post test dan pre test Hasil Belajar Akuntansi aspek kognitif kelas kontrol. (7) Menentukan perbandingan selisih nilai post test dan pre test Hasil Belajar Akuntansi aspek kognitif serta perbandingan hasil angket Aktivitas Belajar Akuntansi kelas eksperimen dan kelas kontrol untuk menentukan perbedaan yang timbul dengan cara membuat histogram perbandingan Aktivitas dan Hasil Belajar Akuntansi kelas eksperimen dan kelas kontrol. (8) Melakukan uji prasyarat analisis (uji normalitas dan uji homogenitas) dan uji hipotesis (uji-t).

\section{Data, Intrumen, dan Teknik Pengumpulan}

\section{a) Data}

Teknik pengumpulan data yang digunakan dalam penelitian ini adalah observasi, kuesioner, tes, dan dokumentasi. Instrumen penelitian yang digunakan yaitu lembar observasi, angket dan tes.

(1) Observasi menurut Sutrisno Hadi dalam Sugiyono (2012: 203) adalah suatu proses biologis dan psikologis yang berupa pengamatan dan ingatan. Observasi digunakan untuk memperoleh data mengenai Aktivitas belajar siswa dalam pembelajaran Akuntansi. (2) kuesioner menurut Sugiyono (2012: 199) merupakan teknik pengumpulan data yang dilakukan dengan memberi seperangkat pertanyaan atau pernyataan tertulis kepada responden untuk dijawabnya. Angket digunakan untuk mengetahui tingkat Aktivitas Belajar Akuntansi siswa berdasarkan model pembelajaran yang diterapkan. (3) Tes adalah alat atau prosedur yang digunakan untuk mengetahui atau mengukur sesuatu dalam suasana dengan cara, dan aturan-aturan yang sudah ditentukan (Suharsimi Arikunto, 2012: 53). Tes digunakan untuk memperoleh data kemampuan kognitif siswa di awal dan akhir pembelajaran. (4) Dokumentasi menurut Sugiyono (2010: 329) merupakan catatan peristiwa yang sudah berlalu. Dokumentasi digunakan untuk mengetahui data siswa serta sebagai acuan dalam membuat Rencana Pelaksanaan Pembelajaran serta pertanyaan atau soal yang digunakan.

\section{b) Teknik Analisis Data}

(1) Analisis Aktivitas Belajar Akuntansi 
(a). Analisis hasil observasi

$\%$ Aktivitas Belajar Akuntansi $=\frac{\text { skor hasil aktivitas belajar akuntansi }}{\text { skor maksimal }} \times 100 \%$

(b). Analisis hasil angket

NP Aktivitas Belajar Akuntansi $=\frac{R}{S M} \times 100 \%$

Keterangan:

NP : Nilai persen Aktivitas Belajar Akuntansi yang dicari

R : Skor Aktivitas Belajar

Akuntansi yang diperoleh siswa

SM : Skor maksimum ideal dari tes yang bersangkutan (Jumlah siswa hadir $\mathrm{x} 23 \mathrm{x} 4$ )

100: Bilangan tetap

(2)Analisis Hasil Belajar Akuntansi

(a). Menghitung rata-rata nilai kelas

$$
M e=\frac{\sum x i}{N}
$$

Keterangan:

Me : Rata - rata (mean)

$\Sigma x i \quad$ Jumlah semua nilai

$\mathrm{N}$ : Jumlah individu

(b). Menghitung persentase ketuntasan nilai Hasil Belajar Akuntansi

$$
K B=\frac{T}{T t} \times 100 \%
$$

Keterangan:

$\mathrm{KB}$ : ketuntasan belajar

$\mathrm{T}$ : jumlah siswa yang memenuhi KKM 77.

$\mathrm{Tt}$ : jumlah siswa yang mengikuti tes.

Uji prasyarat analisis Normalitas, homogenitas dan uji hipotesis dilakukan terhadap data pre test, post test dan Angket Aktivitas Belajar Akuntansi siswa.

(3)Uji Normalitas

Menurut Sugiyono (2010: 76) suatu data yang membentuk distribusi normal bila jumlah data di atas dan di bawah rata-rata adalah sama, demikian juga dengan simpangan bakunya. Uji normalitas dalam penelitian ini menggunakan uji Kolmogorov-Smirnov (Uji K-S) menggunakan bantuan SPSS 16.0. Uji K$S$ diberi simbol $D_{n}$ yang dapat diperoleh dengan rumus berikut:

$$
\mathrm{D}_{\mathrm{n}}=\max \left|\mathrm{F}_{\mathrm{e}}-\mathrm{F}_{\mathrm{o}}\right|
$$

$\mathrm{D}_{\mathrm{n}}$ : deviasi absolut yang tertinggi

$\mathrm{F}_{\mathrm{e}}$ : frekuensi harapan

$\mathrm{F}_{\mathrm{o}}$ : frekuensi observasi

(4) Uji Homogenitas

Digunakan untuk mengetahui data yang diambil mempunyai varian yang sama atau tidak dengan cara membandingkan kedua varian menggunakan uji $\mathrm{F}$ dengan rumus sebagai berikut:

$$
F=\frac{\text { varians terbesar }}{\text { varians terkecil }}
$$

Bila $F_{\text {hitung }}<F_{\text {tabel }}$ maka varians data yang akan dianalisis homogen, sebaliknya jika $F_{\text {hitung }}>F_{\text {tabel }}$ maka varians data yang akan dianalisis tidak homogen. Pengujian homogenitas dalam penelitian ini dilakukan dengan analisis levene's test menggunakan SPSS 16.0. Persyaratan homogenitas jika probabilitas (sig) $>0,05$ dan jika probabilitas (sig) $<0,05$ maka data tersebut tidak homogen.

(5)Uji Hipotesis

dilakukan untuk mengetahui ada atau tidak perbedaan yang signifikan dari Aktivitas dan Hasil Belajar Akuntansi siswa antara kelas eksperimen dan kelas kontrol dengan menggunakan uji statistik parametris rumus t-test. Jika data tidak homogen:

$$
t=\frac{\overline{x_{1}}-\overline{x_{2}}}{\sqrt{\frac{s_{1}^{2}}{n_{1}}+\frac{s_{2}^{2}}{n_{2}}}}
$$

Jika data homogen:

$$
t=\frac{\bar{X}_{1}-\bar{X}_{2}}{\sqrt{\frac{\left(n_{1}-1\right) S_{1}^{2}+\left(n_{2}-1\right) S_{2}^{2}}{n_{1}+n_{2}-2}\left(\frac{1}{n_{1}}+\frac{1}{n_{2}}\right)}}
$$

Keterangan:

$\overline{x_{1}}$ : Rata-rata sampel 1

$\overline{x_{2}}$ : Rata-rata sampel 2

$s_{1}^{2}$ : Varians sampel 1

$s_{2}{ }^{2}$ : Varians sampel 2

$n_{1}$ : Jumlah sampel 1

$n_{2}$ : Jumlah sampel 2

Nilai t $t_{\text {hitung }}$ tersebut selanjutnya dibandingkan dengan nilai $t_{\text {tabel. }}$ Jika didapatkan hasil $t_{\text {hitung }}<t_{\text {tabel }}$ maka terdapat perbedaan yang signifikan. 
Dalam penelitian ini, pengujian hipotesis data dari hasil kedua kelas diolah dengan uji t sampel bebas (independent $t$ test) menggunakan bantuan analisis program SPSS 16.0. Kriteria pengujian hipotesis adalah jika nilai sig $<0,05$ maka $\mathrm{H}_{0}$ ditolak sehingga dapat disimpulkan terdapat perbedaan yang signifikan antara Aktivitas dan Hasil Belajar Akuntansi kelas eksperimen dan kelas kontrol, dan jika nilai sig > 0,05 maka $\mathrm{H}_{0}$ diterima atau tidak ada perbedaan antara Aktivitas dan Hasil Belajar Akuntansi kelas eksperimen dan kelas kontrol.

\section{HASIL PENELITIAN DAN PEMBA- HASAN}

\section{Uji Analisis Data}

a) Uji Prasyarat Analisis

(1) Uji Normalitas

Tabel 3. Normalitas data Materi I

\begin{tabular}{|c|l|c|c|}
\hline No & \multicolumn{1}{|c|}{ Keterangan } & Sig & Kesimpulan \\
\hline Normalitas Data Materi Pokok I & .660 & Normal \\
\hline 1 & Pre test Eksperimen & .576 & Normal \\
\hline 2 & Post test Eksperimen & .796 & Normal \\
\hline 3 & Selisih (Post test - Pre test $)$ & .952 & Normal \\
\hline 4 & Angket Aktivitas Eksperimen & .205 & Normal \\
\hline 5 & Pre test Kontrol & .319 & Normal \\
\hline 6 & Post test Kontrol & .084 & Normal \\
\hline 7 & Selisih (Post test - Pre test $)$ & .591 & Normal \\
\hline 8 & Angket Aktivitas Kontrol & \multicolumn{3}{|c}{} \\
\hline
\end{tabular}

Tabel 4. Normalitas data Materi II

\begin{tabular}{|c|c|c|c|}
\hline \multicolumn{4}{|c|}{ Normalitas Data Materi Pokok II } \\
\hline 9 & Pre test Eksperimen & .983 & Normal \\
\hline 10 & Post test Eksperimen & .162 & Normal \\
\hline 11 & Selisih (Post test - Pre test $)$ & .967 & Normal \\
\hline 12 & Angket Aktivitas Eksperimen & .567 & Normal \\
\hline 13 & Pre test Kontrol & .977 & Normal \\
\hline 14 & Post test Kontrol & .304 & Normal \\
\hline 15 & Selisih (Post test - Pre test) & .849 & Normal \\
\hline 16 & Angket Aktivitas Kontrol & .467 & Normal \\
\hline
\end{tabular}

Tabel 5. Normalitas data rata-rata

\begin{tabular}{|c|l|c|c|}
\hline No & \multicolumn{1}{|c|}{ Keterangan } & Sig & Kesimpulan \\
\hline Normalitas Data Rata-rata & .832 & Normal \\
\hline 17 & $\begin{array}{l}\text { Aktivitas Belajar Akuntansi } \\
\text { Eksperimen }\end{array}$ & .641 & Normal \\
\hline 18 & Hasil Belajar Akuntansi Eksperimen & .579 & Normal \\
\hline & Aktivitas Belajar Akuntansi Kontrol & .472 & Normal \\
\hline & Hasil Belajar Akuntansi Kontrol & .47 &
\end{tabular}

Tabel tersebut menunjukkan pre test, post test dan Angket Aktivitas Belajar Akuntansi siswa kelas eksperimen (X Akuntansi 2) dan kelas kontrol (X Akuntansi 1) pada materi pokok Pencatatan pada Buku Jurnal Umum dan Pemrosesan Entri Jurnal memiliki nilai signifikansi yang semuanya $>0,05$, rata-rata atas Aktivitas dan Hasil Belajar Akuntansi juga memiliki nilai signifikansi $>0,05$ sehingga dapat disimpulkan bahwa semua data berdistribusi normal.

(2) Uji Homogenitas

\section{Tabel 6. Homogenitas Data}

\begin{tabular}{|c|l|c|c|}
\hline No & \multicolumn{1}{|c|}{ Keterangan } & Sig & Kesimpulan \\
\hline Homogenitas Data Materi Pokok I & .321 & Homogen \\
\hline 1 & Pre test & .882 & Homogen \\
\hline 2 & Post test & .936 & Homogen \\
\hline 3 & Selisih (Post test - Pre test) & .730 & Homogen \\
\hline 4 & Angket Aktivitas Belajar Akuntansi & \multicolumn{5}{|l|}{} \\
\hline \multicolumn{4}{|l|}{ Homogenitas Data Materi Pokok II } \\
\hline 5 & Pre test & .936 & Homogen \\
\hline 6 & Post test & .558 & Homogen \\
\hline 7 & Selisih (Post test - Pre test) & .292 & Homogen \\
\hline 8 & Angket Aktivitas Belajar Akuntansi & .915 & Homogen \\
\hline Homogenitas Data Rata-rata & .876 & Homogen \\
\hline 9 & Aktivitas Belajar Akuntansi & .102 & Homogen \\
\hline 10 & Hasil Belajar Akuntansi & \multicolumn{3}{|l}{}
\end{tabular}

Berdasarkan kedua tabel dalam uji homogenitas di atas menunjukkan bahwa hasil uji homogenitas memiliki nilai signifikansi > 0,05, diperoleh kesimpulan bahwa data dalam penelitian materi pokok I dan II serta rata-rata atas data Aktivitas dan Hasil Belajar Akuntansi dari kedua kelas adalah homogen.

b) Uji Hipotesis

Tabel 7. Hasil uji-t

\begin{tabular}{|c|c|c|c|c|c|}
\hline & $t_{\text {hitung }}$ & $t_{\text {tabel }}$ & df & $\begin{array}{c}\text { Sig. } \\
\text { (2-tailed) }\end{array}$ & Kesimpulan \\
\hline \multicolumn{6}{|c|}{$T$-test Data Rata-rata } \\
\hline $\begin{array}{l}\text { Aktivitas } \\
\text { Belajar } \\
\text { Akuntansi }\end{array}$ & 3,178 & 2,00030 & 60 & .001 & Ada perbedaan \\
\hline $\begin{array}{l}\text { Hasil } \\
\text { Belajar } \\
\text { Akuntansi }\end{array}$ & 4,247 & 2.00030 & 60 & .000 & Ada perbedaan \\
\hline
\end{tabular}

Berdasarkan hasil uji-t dapat disimpulkan bahwa H0 ditolak yang artinya Ha diterima, yaitu: (1) Terdapat perbedaan yang signifikan antara Aktivitas Belajar Akuntansi siswa dalam proses pembelajaran menggunakan Model Pembelajaran Kooperatif Tipe Numbered Heads Together (NHT) Berbantu Media Kartu dibandingkan dengan Metode Diskusi. (2) Terdapat perbedaan yang signifikan antara Hasil Belajar Akuntansi siswa dalam proses 
pembelajaran menggunakan Model Pembelajaran Kooperatif Tipe Numbered Heads Together (NHT) Berbantu Media Kartu dibandingkan dengan Metode Diskusi.

\section{Pembahasan Hasil Penelitian}

Berikut ini merupakan perbandingan Aktivitas dan Hasil Belajar Akuntansi siswa di kelas eksperimen dan kelas kontrol:

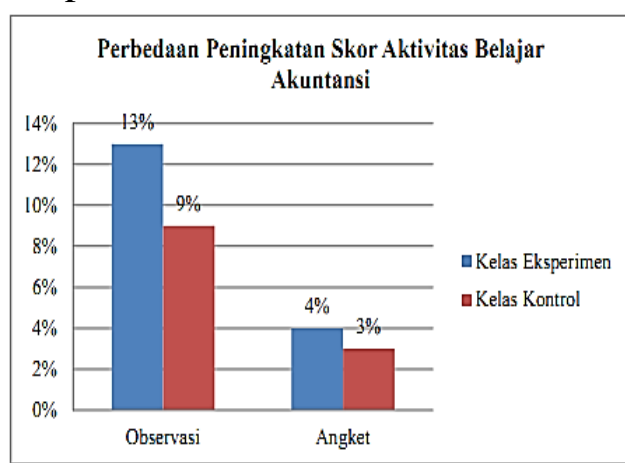

Gambar 1. Perbedaan Peningkatan Skor Aktivitas Belajar Akuntansi

Secara keseluruhan peningkatan di kelas eksperimen dengan menggunakan Model Pembelajaran Numbered Heads Together (NHT) Berbantu Media Kartu lebih tinggi dibandingkan di kelas kontrol yang hanya menggunakan Metode Diskusi. Sesuai dengan pendapat Slameto (2010: 65) bahwa penggunaan metode pembelajaran yang variatif dapat mengatasi beberapa permasalahan yang sering terjadi di kelas seperti rendahnya aktivitas siswa.

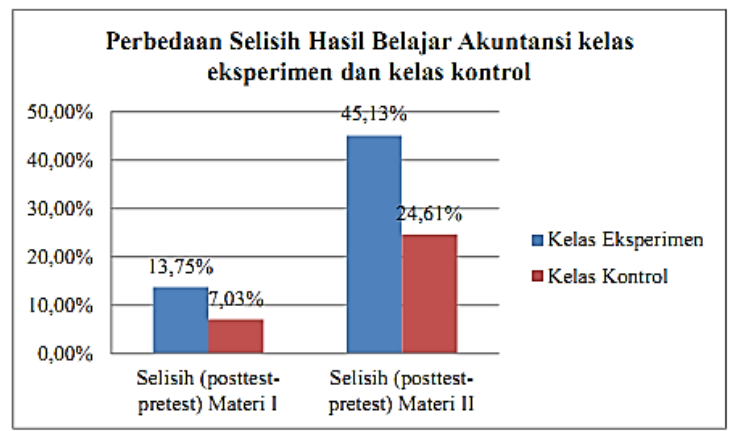

Gambar 2. Perbedaan Selisih Hasil Belajar Akuntansi Kelas
Eksperimen dan Kelas Kontrol

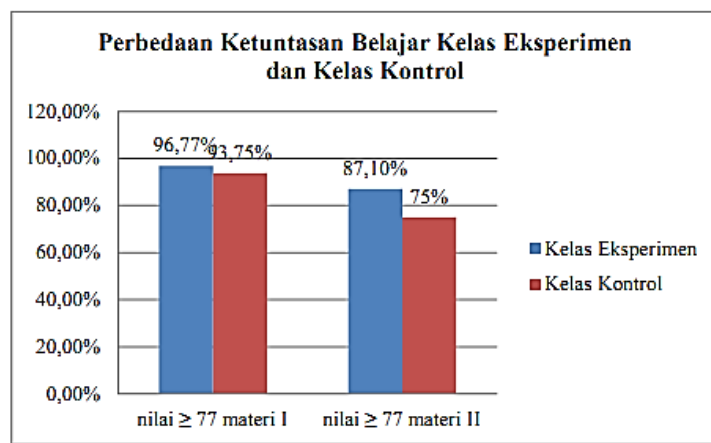

Gambar 3. Perbedaan Ketuntasan

$\begin{array}{ll}\text { Belajar } & \text { Kelas } \\ \text { Eksperimen dan } & \text { Kelas } \\ \text { Kontrol } & \end{array}$

Penelitian ini menunjukkan bahwa selisih peningkatan Hasil Belajar Akuntansi khususnya ranah kognitif siswa dengan menggunakan Model Pembelajaran Kooperatif Tipe Numbered Heads Together (NHT) Berbantu Media Kartu lebih tinggi dibandingkan dengan Metode diskusi. Hal tersebut dapat dilihat dari persentase peningkatan selisih nilai pre test dan post test Hasil Belajar Akuntansi dalam materi pokok I dan materi pokok II. Ketuntasan belajar mengalami sedikit penurunan dalam materi pokok Pemrosesan Entri Jurnal dikarenakan materi tersebut tergolong baru bagi para siswa sedangkan alokasi waktu pertemuan penelitian terbatas, guru menyiasatinya dengan memberikan pengayaan (enrichment) untuk dikerjakan sebagai tugas rumah bagi masing-masing siswa, beda halnya dengan materi Pencatatan pada Buku Jurnal Umum, para siswa sebelumnya pernah sedikit mendapatkan materi tersebut pada mata pelajaran Pengantar Akuntansi dan Keuangan.

Penerapan Model Pembelajaran Kooperatif Tipe Numbered Heads Together (NHT) Berbantu Media Kartu memiliki peran dalam meningkatkan Hasil Belajar Akuntansi lebih tinggi pada kelas eksperimen dibandingkan pada 
kelas kontrol yang hanya menggunakan Metode Diskusi. Sesuai dengan pendapat Wina Sanjaya (2013: 250) bahwa salah satu keunggulan model pembelajaran kooperatif adalah mampu untuk meningkatkan hasil akademik siswa.

Berdasarkan seluruh analisis di atas dapat diketahui bahwa pembelajaran dengan Model Pembelajaran Kooperatif Tipe Numbered Heads Together (NHT) Berbantu Media Kartu dapat membantu siswa untuk meningkatkan Aktivitas dan Hasil Belajar Akuntansi. Terbukti dengan Aktivitas dan Hasil Belajar Akuntansi khususnya ranah kognitif pada kelas eksperimen lebih tinggi daripada kelas kontrol. Oleh karena itu, dapat diambil kesimpulan bahwa terdapat Perbedaan Model Pembelajaran Kooperatif Tipe Numbered Heads Together (NHT) Berbantu Media Kartu dan Metode Diskusi dalam Meningkatkan Aktivitas dan Hasil Belajar Akuntansi Siswa Kelas $\mathrm{X}$ Akuntansi SMK Negeri 1 Pengasih Tahun Ajaran 2014/2015. Hal ini juga didukung oleh penelitian Annik Qurniawati (2013) yang menyimpulkan bahwa metode pembelajaran kooperatif tipe Numbered Heads Together (NHT) dengan media kartu pintar dan kartu soal efektif untuk meningkatkan prestasi belajar siswa pada materi pokok Hidrokarbon kelas X SMA Negeri 8 Surakarta tahun pelajaran 2012/2013

\section{SIMPULAN DAN SARAN}

\section{Simpulan}

Berdasarkan deskripsi data dan pembahasan hasil penelitian dapat ditarik beberapa kesimpulan sebagai berikut:

a. Terdapat perbedaan yang signifikan antara pembelajaran yang menggunakan Model Pembelajaran Kooperatif Tipe Numbered Heads Together (NHT) Berbantu Media Kartu dibandingkan dengan Metode Diskusi dalam meningkatkan Aktivitas Belajar Akuntansi siswa kelas X Akuntansi SMK Negeri 1 Pengasih. Hasil uji-t
Aktivitas Belajar Akuntansi berdasarkan data rata-rata didapatkan hasil nilai thitung > ttabel $(3,178>2,00030)$. Perbedaan persentase peningkatan hasil observasi dan angket Aktivitas Belajar Akuntansi yaitu observasi di kelas eksperimen (X AK 2) menunjukan peningkatan sebesar $13 \%$, sedangkan di kelas kontrol (X AK 1) menunjukkan peningkatan sebesar 9\%. Hasil angket di kelas eksperimen (X AK 2) menunjukan peningkatan sebesar $4 \%$, sedangkan di kelas kontrol (X AK 1) menunjukkan peningkatan sebesar 3\%.

b. Terdapat perbedaan yang signifikan antara pembelajaran yang menggunakan Model Pembelajaran Kooperatif Tipe Numbered Heads Together (NHT) Berbantu Media Kartu dibandingkan dengan Metode Diskusi dalam meningkatkan Hasil Belajar Akuntansi siswa kelas X Akuntansi SMK Negeri 1 Pengasih. Hasil uji-t untuk Hasil Belajar Akuntansi berdasarkan data rata-rata selisih nilai post test - pre test didapatkan hasil nilai thitung > ttabel $(4,247>2,00030)$. Perbedaan peningkatan Hasil Belajar Akuntansi (selisih post test - pre test) dalam materi I kelas eksperimen lebih tinggi sebesar $13,75 \%$ sedangkan kelas kontrol hanya sebesar 7,03\%, sama halnya dalam materi Pemrosesan Entri Jurnal kelas eksperimen lebih tinggi sebesar 45,13\% sedangkan di kelas kontrol hanya sebesar 24,61\%. Ketuntasan belajar kelas eksperimen juga lebih tinggi dibanding kelas kontrol. Pada materi I di kelas eksperimen terdapat 96,77\% siswa yang tuntas, di kelas kontrol hanya sebesar $93,75 \%$ siswa yang tuntas. Pada materi II di kelas eksperimen terdapat $93,75 \%$ siswa yang tuntas, di kelas kontrol hanya sebesar $75 \%$ siswa yang tuntas. 
2. Saran

\section{a. Bagi Guru}

Indikator yang masih memerlukan perhatian khusus untuk guru terutama di kelas yang menggunakan metode diskusi yaitu pada aspek mengajukan dan menjawab pertanyaan (oral activities), mengingat dan memecahkan soal (mental activities) dan menaruh minat pada pembelajaran yang sedang berlangsung (emotional activites), hal tersebut dapat digunakan menjadi refleksi bagi guru untuk melakukan inovasi dalam penggunaan model pembelajaran. Model Pembelajaran Kooperatif Tipe Numbered Heads Together (NHT) Berbantu Media Kartu merupakan salah satu variasi model yang dapat digunakan guru dalam mengelola proses pembelajaran.

b. Bagi Peneliti Selanjutnya

Sebaiknya mampu berinovasi lebih kreatif terhadap penerapan Pembelajaran Kooperatif Tipe Numbered Heads Together beserta media yang digunakan. Jika ingin melakukan penelitian kuasi eksperimen harus memperhatikan faktor guru dan jam pelajaran juga perlu untuk disamakan, selain itu usahakan untuk mencari sekolah dengan jumlah kelas lebih dari dua dalam tingkat kelas yang akan diteliti, sehingga dapat melakukan uji coba instrumen di kelas lain dalam sekolah yang sama.

\section{DAFTAR PUSTAKA}

Amat Jaedun. (2011). Metodologi Penelitian Eksperimen. Yogyakarta: Puslit Dikdasmen Lemlit UNY.

Annik Qurniawati. (2013). Efektivitas Metode Pembelajaran Kooperatif Tipe Numbered Head Together (NHT) Dengan Media Kartu Pintar Dan Kartu Soal Terhadap Prestasi Belajar Siswa Pada Materi Pokok
Hidrokarbon Kelas X Semester Genap SMA Negeri 8 Surakarta Tahun Pelajaran 2012/2013. Skripsi. Surakarta: Pendidikan Kimia PMIPA FKIP UNS.

Kamus Besar Bahasa Indonesia (KBBI) Kamus versi online/daring (dalam jaringan). Kartu. Diakses melalui http://kbbi.web.id/kartu pada tanggal 20 Maret 2014 pukul 08.00 WIB.

Nana Sudjana. (2011). Penilaian Hasil Proses Belajar Mengajar. Bandung: Remaja Rosdakarya.

Sardiman A.M. (2011). Interaksi dan Motivasi Belajar Mengajar. Jakarta: Raja Grafindo Persada.

Slameto. (2010). Belajar dan Faktor Faktor Yang Mempengaruhinya. Jakarta: Rineka Cipta.

Sugiyono. (2012). Metode Penelitian Pendidikan. Bandung: Alfabeta.

(2010). Statistika Untuk Penelitian. Bandung: Alfabeta.

Suharsimi Arikunto. (2012). Dasar - Dasar Evaluasi Pendidikan Edisi 2. Jakarta: Grafika.

Syaiful Bahri Djamarah. (2013). Strategi Belajar Mengajar. Jakarta: Rineka Cipta.

(2010). Guru dan Anak Didik dalam Interaksi Edukatif: Suatu Pendekatan Teoritis Psikologis. Jakarta: Rineka Cipta.

Trianto. (2012). Panduan Lengkap Penelitian Tindakan Kelas (Classroom Action Research): Teori dan Praktik. Jakarta: Prestasi Pustakarya.

(2010). Mendesain Model Pembelajaran Inovatif-Progresif: 
Jurnal Pendidikan Akuntansi Indonesia, Vol. XIII, No.1, Tahun 2015

Ristiningsih Mulyawati \& Sumarsih

$45-54$

Konsep, Landasan, dan

Implementasinya pada Kurikulum

Tingkat Satuan Pendidikan (KTSP).

Jakarta: Prestasi Pustakarya.

Wina Sanjaya. (2013). Strategi

Pembelajaran Berorientasi Standar

Proses Pendidikan. Jakarta: Prenada

Media Group. 